\title{
Urgensi Profesionalisme Guru di Pendidikan Sekolah Dasar
}

\author{
Hamni Fadlilah Nasution \\ Institut Agama Islam Negeri Padangsidimpuan \\ hamnifadlilahnasution@gmail.com
}

\begin{abstract}
The low quality of education in Indonesia can also be known from the Human Development Report, which states that the Human Development Index for 2004 Indonesia position is ranked 111 th out of 177 countries surveyed. Teachers play an important role in the progress of education quality. Professional teachers are teachers who are able to master and control changes with science and technology insights. Professional teachers are teachers who are able to run the competencies they have. Four components of the competency standards that teachers must possess are: Personality competence, Pedagogic competence, Professional competence and social competence. The development of professionalism of elementary school teachers can also be pursued through a system called educational supervision, certification, with a professional teacher coaching system (SPP-Teacher) and learning tasks. The coaching program is useful to improve the quality of teachers so that a positive impact on the success of education.
\end{abstract}

Keywords : Professional Teachers, Elementary School

\begin{abstract}
Abstrak : Kualitas yang rendah dalam pendidikan indonesia bisa dikenali dari pengembangan sumber daya manusianya. Laporan, yang menyatakan bahwa perkembangan index manusia untuk tahun 2004 indonesia berada di posisi 111 dari 177 negara yang di periksa. Guru memainkan peranan yang sangat penting dalam meningkatkan kualitas pendidikan. Guru yang professional adalah guru yang bisa menguasai dan memeriksa perubahan yang terjadi di dalam ilmu pengetahuan dan tekhnologi. Guru yang professional adalah guru yang bisa sejalan dengan kemampuan yang mereka miliki. Empat komponen dari standar kemampuan yang guru harus miliki adalah: kemampuan kepribadian, kemampuan keprofesionalan, kemampuan kompetensi, kemampuan secara sosial. Pengembangan dari keprofesionalan dari guru Sekolah Dasar juga bisa ditingkatkan dari sistem yang disebut educational supervision, certification, yang mana guru yang profesional mengadakan coaching sistem (SPP-Teacher) dan pembelajaran soalsoal. Program pelatihan ini bertujuan untuk meningkatkan kualitas dari guru-guru untuk memperoleh pengaruh yang positive dalam keberhasilan pendidikan.
\end{abstract}

Kata Kunci : Profesionalisme Guru. Sekolah Dasar

Ar-Riayah : Jurnal Pendidikan Dasar vol.1 no. 01, 2017

STAIN Curup - Bengkulu I p ISSN 2580-362X; e ISSN 2580-3611 


\section{PENDAHULUAN}

Pendidikan telah dilakukan oleh manusia pertama di muka bumi ini, yaitu sejak Nabi Adam. Dalam Al-Quran dinyatakan bahwa proses pendidikan terjadi pada saat Adam berdialog dengan Allah. Pendidikan ini muncul karena adanya keinginan pada diri Adam serta kehendak Allah sebagai pendidik langsung Adam untuk mengajarkan beberapa nama. Hal ini dijelaskan dalam alQuran Surat al-Baqarah ayat 31.

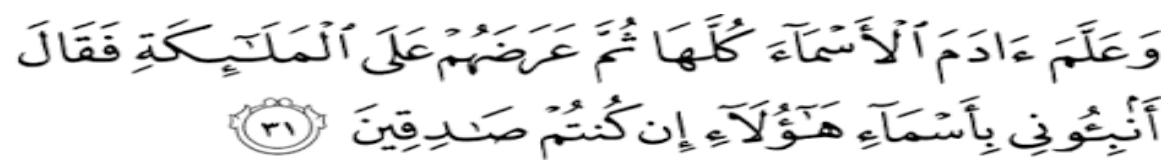

Artinya: "Dan Dia mengajarkan kepada Adam Nama-nama (benda-benda) selurubnya, kemudian mengemukakannya kepada Para Malaikat lalu berfirman: "Sebutkanlah kepada-Ku nama benda-benda itu jika kamu memang benar orang-orangyang benar!"

Jelas sekali bahwa manusia hidup di dunia ini membutuhkan pendidikan. Karena tanpa pendidikan hidup manusia akan tidak teratur bahkan bisa merusak sistem kehidupan di dunia. Hal ini terbukti dengan pendidikan Nabi Adam yang diterima langsung dari Tuhan.

Guru adalah salah satu di antara faktor pendidikan yang memiliki peranan yang paling strategis, sebab gurulah sebetulnya yang paling menentukan di dalam terjadinya proses belajar mengajar. Peran guru sangat vital bagi pembentukan kepribadian, cita-cita, dan visi misi yang menjadi impian hidup anak didiknya di masa depan. Di balik kesuksesan murid, selalu ada guru profesional yang memberikan inspirasi dan motivasi besar pada dirinya sebagai sumber stamina dan energi untuk selalu belajar dan bergerak mengejar ketertinggalan, menggapai kemajuan, menorehkan prestasi spektakuler dalam mencapai kemajuan suatu bangsa. 
Menurut Tim Broad-Based Education (BBE) Depdiknas (Tim BBE, 2002:

1) indikator rendahnya mutu pendididkan di Indonesia, antara lain : (1) NEM SD sampai Sekolah Menengah relatif rendah dan tidak menunjukkan kenaikan yang berarti, (2) adanya keluhan dari dunia usaha bahwa lulusan yang memasuki dunia kerja belum memiliki kesiapan kerja yang baik, (3) adanya ketidakpuasan yang berjenjang, dimana pihak SLTP merasa bekal lulusan SD kurang baik untuk memasuki SLTP, kalangan Sekolah Menengah merasa bekal lulusan SLTP tidak siap untuk mengikuti pembelajaran di Sekolah Menengah, demikian juga pihak perguruan tinggi merasa bahwa lulusan Sekolah Menengah belum memiliki bekal yang cukup untuk mengikuti perkuliahan di perguruan tinggi, (4) adanya gejala lulusan SLTP dan Sekolah Menengah mengalami kesulitan untuk mendapatkan pekerjaan sehingga mereka ini menjadi penganggur. ${ }^{1}$

Persentase melek huruf penduduk di Negara ASEAN tahun 2000-2004 adalah sebagai berikut :

\begin{tabular}{clcl}
\hline No & \multicolumn{1}{c}{ Negara } & & Persentase \\
\hline 1 & Indonesia & 87,9 & \\
2 & Malaysia & 88,7 & \\
3 & Singapura & 92,5 & \\
4 & Filipina & 92,6 & \\
5 & Brunei Darussalam & 93,9 & \\
\hline
\end{tabular}

Sumber : Litbang, Kompas 2005

Kemampuan untuk melek huruf diperoleh warga dari jenjang pendidikan. Tentu hal ini menjadi tugas berat dunia pendidikan.

Rendahnya mutu pendidikan di Indonesia juga dapat diketahui dari Human Development Report, yang menyatakan bahwa Indeks Pembangunan Manusia (Human Developemnt Index) Indonesia pada tahun 2001 berada pada urutan ke 105 dari 108 negara yang disurvei sedangkan untuk tahun 2004

${ }^{1}$ Tim Broad-Based Education. (2002) Konsep Pendidikan Berorientasi Kecakapan Hidup (life Skill) Melalui Pendekatan Pendidikan Berbasis Luas (Broad-Based Education-BBE). Jakarta : Depdiknas 
posisi Indoensia berada pada urutan ke 111 dari 177 negara yang disurvei (Human Development Report 2004). Hasil studi the Third International Mathematics and Science Study Repeat (TIMSS-R) melaporkan bahwa untuk bidang matematika siswa SLTP Indonesia berada di urutan 34 dan untuk IPA di urutan 32 dari 38 negara yang disurvei di Asia, Australia dan Afrika. Berikut ini adalah tabel rangking Indonesia berdasrkan HDI dibanding beberapa negara

\begin{tabular}{lllllll}
\hline \multirow{2}{*}{ No } & \multirow{2}{*}{ Negara } & 1995 & 2000 & \multicolumn{1}{c}{ Tahun } \\
& & 58 & 76 & 74 & 76 & 73 \\
\hline 1 & Thailand & 59 & 61 & 58 & 59 & 61 \\
2 & Malaysia & 100 & 77 & 85 & 83 & 84 \\
3 & Philipina & 104 & 109 & 112 & 111 & 110 \\
4 & Indonesia & 111 & 99 & 104 & 94 & 85 \\
5 & Cina & 120 & 108 & 109 & 112 & 108 \\
6 & Vietnam & & & & & \\
\hline
\end{tabular}

Salah satu kemampuan dasar yang harus dimiliki oleh seorang guru adalah kemampuan profesional. Kemampuan profesional adalah kemampuan yang berkaitan dengan tugas-tugas guru sebagai pembimbing, pendidik, dan pengajar. Kemudian makalah ini akan menjelaskan tentang kompetensi profesional guru.

Guru yang sesuai dengan kondisi globalisasi adalah guru yang mampu menguasai dan mengendalikan perubahan-perubahan dengan wawasan IPTEK. Mengakomodasi berbagai perubahan ilmu pengetahuan dan teknologi dijadikan bahan pemikiran bagi peserta didik dalam rangka pendidikan dan pelatihan. Penguasan teknologi menjadi faktor kemajuan suatu bangsa yaitu; penguasaan inovasi (45\%0, penguasaan jaringan /networking (25\%), penguasaan teknologi $(20 \%)$ dan kekayaan sumber daya alam hanya $(10 \%) .^{2}$ maka peningkatan profesionalisme guru harus lebih ditingkatkan termasuk juga dalam hal peran pemerintah dalam menyelesaikan masalah pendidikan terutama tantangan

${ }^{2}$ www.kompasiana.com 
menghadapi MEA kedepannya, salah satunya dengan mengalokasikan anggaran pendidikan yang memadai disertai dengan pengawasan pelaksanaan anggaran agar dimanfaatkan untuk meningkatkan profesionalisme guru dan pendidikan di Indonesia serta diharapkan juga akan mampu membawa Indonesia ke gerbang kesuksesan menuju Masyarakat Ekonomi Asean (MEA).

Pemerintah tidak pernah berhenti berupaya meningkatkan profesionalisme guru dan kesejahteraan guru. Pemerintah telah melakukan langkah-langkah strategis dalam kerangka peningkatan kualifikasi, kompetensi, kesejahteraan, serta perlindungan hukum dan perlindungan profesi bagi mereka. Langkah-langkah strategis ini perlu diambil, karena apresiasi tinggi suatu bangsa terhadap guru sebagai penyandang profesi yang bermartabat merupakan pencerminan sekaligus sebagai salah satu ukuran martabat suatu bangsa.

\section{PEMBAHASAN}

\section{A. Pengertian Profesinalisme Guru}

Profesionalisme berasal dari kata profesi. Menurut KKBI profesi berarti. Profesi adalah suatu pekerjaan atau jabatan yang menuntut kehalian tertentu. Artinya suatu pekerjaan atau jabatan yang disebut profesi dapat dipegang oleh seseorang yang telah menempuh pendidikan dan pelatihan secara khusus. ${ }^{3}$ Menurut UU Nomor 14 tahun 2005 tentang guru dan dan dosen, profesional adalah pekerjaan atau kegiatan yang dilakukan memerlukan keahlian, kemahiran, atau kecakapan yang memenuhi standar mutu atau norma tertentu serta memerlukan pendidikan profesi. adalah suatu pekerjaan atau kegiatan.

Suatu pekerjaan dapat dikatakan profesional jika memenuhi persyaratan tertentu. Menurut Ali ada lima persyaratan yang harus dipenuhi antara lain: (1)

\footnotetext{
${ }^{3}$ Kunandar. Guru Profesional Implemantasi Kurikulkum Tingkat satuan Pendidikan (KTSP) dan Sukses dalam Sertifikasi Guru.(Jakarta:PT RajaGrafindo Persada, 2007), hlm.45.
} 
menuntut adanya keterampilan berdasarkan konsep teori ilmu pengetahuan yang mendalam; (2) menekankan pada suatu keahlian dalam bidang tertentu sesuai bidang profesinya; (3) menuntut adanya tingkat pendidikan yang memadai; (4) adanya kepekaan terhadap dampak kemasyarakatan dari pekerjaan yang dilaksanakan (5) memungkinkan perkembangan sejalan dengan dinamika kehidupan. ${ }^{4}$

Guru yang profesional tentunya harus dapat memenuhi persyaratan tersebut. Guru harus memiliki keterampilan atau kompetensi sesuai bidang ilmunya. Bidang ilmu yang dimiliki sesuai dengan bidangnya. Guru juga harus memiliki tingkat pendidikan yang cukup sesuai dengan peraturan yang telah ditetapkan. Seorang guru juga harus peka terhadap masyarakat belajara yang dihadapinya. Dalam artian seorang guru harus mampu menyesuaikan diri dengan kebutuhan siswa. Kondisi siswa yang semakin berkembang menyebabkan seorang guru juga harus terus memperbaiki kemampuan.

Guru memiliki andil yang sangat bersar terhadap keberhasilan pembelajaran di sekolah. Guru membantu perkembangan peserta didik untuk mewujudkan kesuksesan di masa yang akan datang dan meraih hidup yang lebih baik. Dalam benak setiap orang memiliki keyakinan semua itu tidak lepas dari peran seorang guru. Hal ini disebabkan tidak semua orang tua memiliki kemampuan yang baik dari segi pengalaman, pengetahuan maupaun ketersedian waktu untuk mendidik anak-anaknya. Orang tua menyerahkan anaknya kepada guru di sekolah dengan harapan agar anaknya dapat berkembangan secara optimal. Jadi, guru adalah seorang pendidik, pembimbing, pelatih, pengembang kurikulum yang dapat menciptakan kondisi belajar yang kondusif yaitu suasana belajar menyenangkan, menarik dan aman pada siswa untuk berpikir aktif, kreatif dan inovatif dalam mengeksplorasikan kemampuannya.

${ }^{4}$ Ibid. Hlm. 47 
Guru yang profesional menjadi fondasi penentu proses pendidikan yang berkualitas. Untuk dapat menjadi guru profesional, guru diharapkan tidak hanya sebatas menjalankan profesinya tetapi guru harus memiliki kemauan dan kemampuan yang kuat untuk melaksanakan tugasnya dengan kaidah-kaidah profesionalme guru yang dipersyaratkan. Guru era teknologi informasi dan komunikasi (IPTEKS) yang semakin maju sekarang ini bukan hanya sekedar mengajar atau mentransfer ilmu, melainkan harus menjadi manajer dalam proses pembelajaran di sekolah. Setiap guru diharapkan mampu menciptakan kondisi belajar yang menantang kreativitas dan aktivitas siswa, memotivasi siswa, menggunakan multimedia, metode, sumber agar mencapai tujuan pembelajaran yang diharapkan.

Pada kenyataanny, pendidikan kita yang ada di daerah masih banyak ditemukan guru yang berada pada posisi kurang bisa menjalankan pembelajaran yang sesuai dengan yang diharapkan yang menjadi tujuan profesi yang seharusnya. Masih banyak guru yang mengajar di ruangan sempit yang penuh sesak anak didik dengan perlengkapan seadanya, bahkan ada juga para peserta didik yang tidak berpakaian layak. Namun, para guru tetap diharapkan harus mampu melaksanakan pembelajaran yang berharga untuk mendidik generasi penerus anak bangsa. Lebih berat lagi bila dihadapkan pada luapkan perkembangan IPTEK dengan dukungan fasilitas yang minim dan iklim kerja yang kurang menyenangkan. Beban kerja guru di tambah lagi dengan kegiatan akademik yang cukup menyita waktu dan tenaga guru. Guru merupakan salah satu komponen manusiawi dalam proses belajar mengajar yang ikut berperan dalam usaha pembentukan sumber daya manusia yang potensial di bidang pembangunan. Oleh karena itu, guru harus berperan aktif dalam menempatkan kedudukannya sebagai tenaga profesional, sesuai dengan tuntutan masyarakat yang semakin berkembang 
Usman menambahkan persyaratan agar dikatakan suatu pekerjaan profesional yaitu: (1) memiliki kode etik, sebagai acuan dalam melaksanakan tugas dan fungsinya.; (2) memiliki objek layanan yang tetap, dalam hal ini yang menjadi objek seorang guru adalam siswa di sekolah; (3) diakui oleh maysrakat karena memang diperlukan jasanya di masyarakat. Profesi guru adalah salah satu profesi yang sangat urgen dalam perkembangan bangsa. Sehingga guru merupakan profesi yang sangat diperlukan dalam masyarakat dalam memajukan pola pikir masyarakat. ${ }^{5}$

Kode etik guru sering disebut dengan kode etik profesi keguruan. Tujuan kode etik dirumuskan adalah untuk kepentingan anggota dan kepentingan organisasi. Secara umum tujuan mengadakan kode etik menurut Hermawan (1979) adalah: 1) untuk menjungjung tinggi martabat profesi, 2) untuk menjaga dan memelihara kesejahteraan para anggotanya, 3) untuk meningkatkan pengabdian para anggota profesi, 4) untuk meningkatkan mutu profesi dan 4) untuk meningkatkan mutu organisasi profesi. ${ }^{6}$

Dalam prosesnya pembelajaran terjadi timbal balik antara perilaku mengajar, dan pembelajar. Interaksi dalam proses pembelajaran profesi guru menjadi fondasi pengembangan sumber daya manusia yang sangat mendasar dalam tatanan pendidikan, tidak dapat terepas dari wacana persekolahan sebagai sistem. Komponen strategis dalam sistem persekolahan adalah tenaga kependidikan khususnya sosok guru. H.A.R.Tilaar memandang profesi guru pada abad ke 21 berhadapan dengan tiga karakteristik, yaitu; (1) masyarakat teknologi, (2) masyarakat terbuka, (3) masyarakat madani. Adapun proses pendidikan yang dihadapi di masa itu, merupakan suatu interaksi antara pendidik

\footnotetext{
${ }^{5}$ Loc.cit. hlm. 47

${ }^{6}$ Soetjipto. Profesi Keguruan. (Jakarta : Rineka Cipta, 2004). Hlm 31-32
} 
dan peserta didik. Interaksi yang terjadi di masa depan sesuai dengan teknologi yang ada, masyarakat yang terbuka dan demokrasi. ${ }^{7}$

Sehingga seorang guru harus memiliki kemampuan teknologi. Dalam proses pembalajaran seorang guru harus mengaplikasikan teknologi yang ada. Diantaranya, guru menyajikan bahan belajar dalam bentuk slide. Kegiatan pembelajaran dapat ditambahkan dengan memberikan sesuatu yang dapat dilihat secara langsung oleh siswa sehingga siswa berperan aktif.

Guru harus memiliki kompetensi yang dipersyaratkan dalam melakukan tugas pendidikan dan pengajaran agar dapat dikatakan guru profesional. Kompetensi menurut menurut Undang-Undang Republik Indonesia Nomor 14 Tahun 2005 Tentang Guru dan Dosen menyatakan bahwa kompetensi adalah seperangkat pengetahuan, keterampilan, dan perilaku yang harus dimiliki, dihayati, dan dikuasai oleh guru atau dosen dalam melaksanakan tugas keprofesionalan. Pernyataan ini mengandung makna bahwa kompetensi meliputi tugas, keterampilan, sikap, nilai, apresiasi diberikan dalam rangka keberhasilan hidup/penghasilan hidup. Hal tersebut dapat diartikan bahwa kompetensi merupakan perpaduan antara pengetahuan, kemampuan, dan penerapan dalam melaksanakan tugas di lapangan kerja.

Kompetensi profesional seorang guru adalah seperangkat kemampuan yang harus dimiliki oleh seorang guru agar ia dapat melaksanakan tugas mengajarnya dengan berhasil. ${ }^{8}$ Sehingga, kompetensi profesional guru adalah sejumlah kompetensi yang berhubungan dengan profesi yang menuntut berbagai keahlian di bidang pendidikan atau keguruan.

Istilah kompetensi menunjuk pada suatu kemampuan sebab "competence means fitness or ability" yang berarti kemampuan atau kecakapan.

7 Tilaar.Manajemen Pendidikan Nasional.(Bandung : PT. Remaja Rosdakarya.1999). $\operatorname{hlm} .281$

${ }^{8}$ Hamzah B. Uno, Profesi Kependidikan (Jakarta: Sinar Grafika Offset,2008), hlm.18 
Depdiknas menyatakan bahwa kompetensi menunjuk kepada kemampuan melaksanakan sesuatu yang diperoleh melalui pendidikan atau latihan? Sedangkan menurut The National Council for Vocational Qualification (NCVQ) menyatakan bahwa "a competence is defined as the ability to perform an activity within an occupation. Competence is a wide concept which embodies the ability to transfer skills and knowledge to new situations ... within the occupational areas and includes aspects of key skills". Kompetensi merupakan kemampuan untuk menjalankan aktivitas dalam suatu pekerjaan, yang ditunjukkan oleh kemampuan mentransfer keterampilan dan pengetahuan pada situasi yang baru. Sementara itu, Mukminan mengutip pendapat Hall dan Jone yang menyatakan bahwa kompetensi adalah pernyataan yang menggambarkan penampilan suatu kemampuan tertentu secara bulat yang merupakan perpaduan antara pengetahuan, keterampilan dan sikap yang dapat diamati dan diukur. ${ }^{10}$ Oleh sebab itu, seseorang yang memiliki kompetensi berarti yang bersangkutan memiliki kemampuan yang dapat diamati dan diukur.

Guru merupakan tenaga pendidik yang mempunyai tugas pokok melaksanakan kegiatan belajar mengajar. Tugas guru tidaklah ringan karena harus meningkatkan kualitas sumber daya manusia sesuai standar kompetensi tertentu serta norma dan nilai-nilai yang berlaku. Tugas guru meliputi "instruction, education and manajement". Dalam aspek instruction, guru bertugas menstranfer pengetahuan dan keterampilan sesuai dengan kurikulum yang berlaku.

Peraturan pemerintah nomor 19 Tahun 2015 tentang standar nasional pendidikan menyebutkan empat komponen standar kompetensi yang harus dimiliki guru yaitu: (1) Kompetensi kepribadian ; (2) Kompetensi pedagogik ; (3) Kompentensi profesional; (4) Kompetensi sosial.

\footnotetext{
${ }^{9}$ Tim Broad-Based Education, op.cit. hlm 51.

${ }^{10}$ http://staffnew.uny.ac.id
} 
Kompetensi pedagogik meliputi pemahaman guru terhadap peserta didik, perancangan dan pelaksanaan pembelajaran, evaluasi hasil belajar, dan pengembangan peserta didik untuk mengaktualisasikan berbagai potensi yang dimilikinya. Kompetensi kepribadian merupakan kemampuan personal yang mencerminkan kepribadian yang mantap, stabil, dewasa, arif, dan berwibawa, menjadi teladan bagi peserta didik, dan berakhlak mulia. Kompetensi sosial merupakan kemampuan guru untuk berkomunikasi dan bergaul secara efektif dengan peserta didik, sesama pendidik, tenaga kependidikan, orang tua/wali peserta didik, dan masyarakat sekitar. Kompetensi profesional merupakan penguasaan materi pembelajaran secara luas dan mendalam, yang mencakup penguasaan materi kurikulum mata pelajaran di sekolah dan substansi keilmuan yang menaungi materinya, serta penguasaan terhadap stuktur dan metodologi keilmuannya

\section{B. Urgensi Profesionalisme Guru dalam Al-Qur'an}

Islam mengajarkan pendidikan merupakan hal yang sangat urgen untuk dituntut agar memperoleh kebaikan di dunia maupun di akhirat. Firman Allah Swt dalam Al-Qur'an Q.S : Ar-Rahman ayat 33

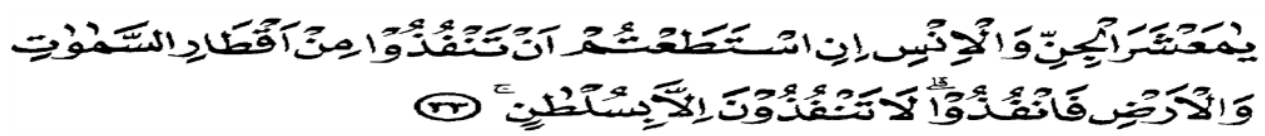

Artinya : "Hai jama'ah jin dan manusia, jika kamu sanggup menembus (melintasi) penjuru langit dan bumi, maka lintasilah, kamu tidak dapat menembusnya kecuali dengan kekuatan.”

Menuntut ilmu merupakan hal yang paling wajib yang dilakukan manusia untuk memperluas wawasan sehingga derajat kita pun bisa terangkat. Ayat ini menjelaskan pentingnya ilmu pengetahuan bagi kehidupan umat manusia. Dengan ilmu pengetahuan, manusia dapat mengetahui benda-benda langit. 
Dengan ilmu pengetahuan, manusia selama ini belum terkuak. Hebat, dapat menjelajahi angkasa raya. Dengan ilmu pengetahuan, manusia mampu menembus sekat-sekat yang ada. Allah memberikan potensi kepada manusia untuk memperolehnya. Potensi yang diberikan berupa akal. Akal ini harus terus diasah, diberdayakan dengan cara belajar dan berkarya. Dengan belajar, manusia bisa mendapatkan ilmu dan wawasan yang baru. Dengan ilmu, manusia dapat berkarya untuk kehidupan yang lebih baik.

Profesional dalam Islam khususnya di bidang pendidikan, seseorang harus benarbenar mempunyai kualitas keilmuan kependidikan dan kenginan yang memadai guna menunjang tugas jabatan profesinya, serta tidak semua orang bisa melakukan tugas dengan baik. Apabila tugas tersebut dilimpahkan kepada orang yang bukan ahlinya maka tidak akan berhasil bahkan akan mengalami kegagalan, sebagaimana sabda nabi Muhammad SAW yang artinya: “Apabila suati perkara diberikan kepada yang bukan ahlinya maka tunggulah akan kehancurannya" (HR. Bukhari).

Di dalam al-Qur'an Allah juga berfirman dalam Q.S. Al-Isra' ayat 84 yaitu:

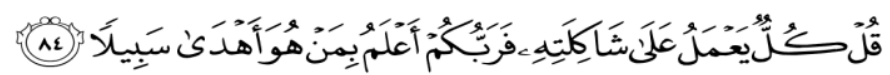

Artinya: "Katakanlah: "Tiap-tiap orang berbuat menurut keadaannya masing masing". Maka Tuhanmu lebih mengetahui siapa yang lebih benar jalannya".

Proses belajar mengajar merupakan suatu proses yang mengandung serangkaian perbuatan guru dan siswa atas dasar hubungan timbal balik yang berlangsung dalam situasi edukatif untuk mencapai tujuan tertentu. Dalam proses belajar mengajar tersirat adanya satu kesatuan kegiatan yang tak terpisahkan ntara siswa yang belajar dan guru yang mengajar. Agar proses 
pembelajaran dapat dilaksanakan secara efektif dan efisien, maka guru mempunyai tugas dan peranan yang penting dalam mengantarkan peserta didiknya mencapai tujuan yang diharapkan. Oleh karena itu, sudah selayaknya guru mempunyai berbagai kompetensi yang berkaitan dengan tugas dan tanggungjawabnya. Dengan kompetensi tersebut, maka akan menjadikan guru profesional, baik secara akademis maupun non akademis.

Masalah kompetensi guru merupakan hal urgen yang harus dimiliki oleh setiap guru dalam jenjang pendidikan apapun. Guru yang terampil mengajar tentu harus pula memiliki pribadi yang baik dan mampu melakukan social adjustment dalam masyarakat. Kompetensi guru sangat penting dalam rangka penyusunan kurikulum. Ini dikarenakan kurikulum pendidikan haruslah disusun berdasarkan kompetensi yang dimiliki oleh guru. Tujuan, program pendidikan, sistem penyampaian, evaluasi, dan sebagainya, hendaknya direncanakan sedemikian rupa agar relevan dengan tuntutan kompetensi guru secara umum. Dengan demikian diharapkan guru tersebut mampu menjalankan tugas dan tanggung jawab sebaik mungkin. ${ }^{11}$

Dalam hubungan dengan kegiatan dan hasil belajar siswa, kompetensi guru berperan penting. Proses belajar mengajar dan hasil belajar para siswa bukan saja ditentukan oleh sekolah, pola, struktur dan isi kurikulumnya, akan tetapi sebagian besar ditentukan oleh kompetensi guru yang mengajar dan membimbing para siswa. Guru yang berkompeten akan lebih mampu mengelola kelasnya, sehingga belajar para siswa berada pada tingkat optimal. ${ }^{12}$ Agar tujuan pendidikan tercapai, yang dimulai dengan lingkungan belajar yang kondusif dan efektif, maka guru harus melengkapi dan meningkatkan kompetensinya. Di antara kriteria-kriteria kompetensi guru yang harus dimiliki meliputi:

1. Kompetensi kognitif, yaitu kompetensi yang berkaitan dengan intelektual.

11 Oemar Hamalik, Pendidikan Guru Berdasarkan Pendekatan Kompetensi, Cet Ke-4, (Jakarta: Bumi Aksara,2006), hal. 36

12 ibid 
2. Kompetensi afektif, yaitu kompetensi atau kemampuan bidang sikap, menghargai pekerjaan dan sikap dalam menghargai hal-hal yang berkenaan dengan tugas dan profesinya.

3. Kompetensi psikomotorik, yaitu kemampuan guru dalam berbagai keterampilan atau berperilaku' ${ }^{13}$.

Profesionalisme pada dasarnya berpijak pada dua kriteria pokok, yakni, merupakan panggilan hidup dan keahlian. Panggilan hidup atau dedikasi dan keahlian menurut Islam harus dilakukan karena Allah Swt. Hal ini akan menjadi tolak ukur nilai keikhlasan dalam melakukan pekerjaan atau tanggung jawabnya sebagai seorang guru. Dalam Islam apapun setiap pekerjaan (termasuk seorang guru), harus dilakukan secara profesional. Maka dedikasi dan keahlian yang mewarnai tanggung jawab untuk terbentuknya profesionalisme guru dalam perspektif pendidikan Islam. Selain itu, ada ungkapan yang tersirat saat Islam mendefinisikan terminologi profesionalisme yakni melimpahkan suatu urusan atau pekerjaan pada ahlinya. ${ }^{14}$

Terbentuk profesionalisme guru dalam perspektif Islam, lebih mengarahkan guru untuk bersikap baik, sopan, moral dan spritualitas sebagai harapan atau cita-cita yang harus dicapai. Selayaknya guru dalam tulang punggung pendidikan harus memiliki eksistensi yang kuat. Dalam perspektif Islam pendidik (guru) akan berhasil bila menjalankan tugas dengan baik, memilki pemikiran kreatif, dan terpadu serta mempunyai kompetensi profesionalisme yang religius.

Guru dalam Islam sebagai pemegang jabatan professional membawa misi ganda dalam waktu yang bersamaan, yaitu misi ilmu pengetahuan dan misi ilmu yang dikaitkan dengan agama. Misi pengetahuan menuntut guru untuk 2003), hal. 44

${ }^{13}$ Nana Sudjana, Dasar-Dasar Proses Belajar Mengajar, (Bandung: Sinar Baru, 1989), hal.18

14 Ibrahim Bafadal, Peningkatan Profesional Guru Sekolab Dasar, Jakarta: Bumi Aksara, 
menyampaikan nilai-nilai pengatahuam kepada murid, sehingga murid dapat menjalankan kehidupan sesuai dengan norma-norma dan berkeyakinan bahwa ilmu yang diperoleh tidak lepas dari kekuasaaan Allah. Misi ilmu pengetahuan menuntut guru menyampaikan ilmu sesuai dengan perkembangan zaman.

Guru adalah sebuah pionir teladan yang hidup. Maknanya, guru disamping mengajarkan ilmu, juga perlu memberikan teladan kepada para peserta didiknya. Dalam proses pembelajaran di sekolah peranan guru sangat penting fungsinya sebagaimana orang tua yang mampu memahami, mengayomi dan memberikan perasaan aman kepada peserta didik. Dalam proses materi keislaman (dalam arti nilai substansi) tidak diberikan hanya oleh guru bidang studi khusus, namun semua guru mampu memahami dan memasukkan nilai-nilai islami dalam semua pelajaran.

Berdasaran hal tersebut, maka setiap guru dalam perspektif Islam hendaknya memiliki kualifikasi: ${ }^{15}$

1) Amanah, yaitu bertanggung jawab dalam keberhasilan proses pedidikan. Ia betul-betul memiliki komitmen yang tinggi untuk membentuk kepribadian Islam pada diri peserta didik. Bila tidak, pendidikan yang diharapkan unggul hanya akan menjadi impian. Karena guru tidak merasa berkewajiban agar peserta didiknya memahami apa yang disampaikannya. Hanya sekedar mengajar saja tanpa peduli dengan kondisi pembelajar.

2) Kafa'ah atau memiliki skill (keahlian) dibidangnya. Pengajar yang tidak menguasai bidang yang diajarkan baik dalam aspek IPTEK dan keahlian maupun tsaqafah Islam tidak akan mampu memberikan hasil optimal pada diri sendiri dan peserta didik. Dalam keseharian, seorang guru didorong mengembangkan wawasan, baik terkait dengan dunia pendidikan secara umum maupun bidang ilmu yang menjadi spesialisasinya. Di samping itu, guru dituntut pula untuk memahami dengan seksama aspek paradigma pendidikan sesuai jenjangnya.

3) Himmah atau memiliki etos kerja yang baik. Disiplin, bertanggung jawab, kreatif, inivatif, dan taat pada akad kerja dan tugas merupakan salah satu

${ }^{15}$ Muhammad Ismail Yusanto, dkk, Menggagas Pendidikan Islami, cet. I, (Bogor: AlAzhar, 2004), hal. 92-93 
karakter orang yang beretos kerja tinggi. Hal ini harus benar-benar dipegang teguh oleh seorang guru. Karena guru adalah sesorang yang ditiru.

4) Berkepribadian Islami. Guru harus menjadi teladan bagi siswanya agar tidak hanya sekedar menjalankan fungsi mengajar melainkan juga fungsi mendidik artinya upaya menanamkan kepribadian Islam kepada siswa harus dimulai dengan tersedianya guru yang berkepribadian Islam kuat.

Berdasarkan pembahasan di atas jelaslah bahwa guru dalam perspektif pendidikan Islam hendaknya memiliki kompetensi kepribadian sebagai teladan, kemampuan dalam berbagai kemajuan termasuk IPTEK, dan yang terpenting dalam pendidikan Islam adalah adanya nilai ikhlas ibadah karena Allah. Komponen kemampuan diri dan ilmu pengetahuan serta teknologi yang terus dinamis dibarengi dengan niat karena Allah maka tujuan pendidikan dalam menciptakan generasi muslim yang kualifikasi dunia akhirat dapat terwujud.

\section{Urgensi Profesionalisme Guru di Pendidikan Sekolah Dasar}

Tingkat satuan pendidikan yang dianggap sebagai dasar pendidikan adalah Sekolah Dasar. Di sekolah inilah anak didik mengalami proses pendidikan dan pembelajaran. Secara umum pengertian Sekolah Dasar dapat kita katakan sebagai institusi pendidikan yang menyelenggarakan proses pendidikan dasar dan mendasari proses pendidikan selanjutnya.

Pendidikan Sekolah Dasar bukan hanya memberikan bekal kemampuan dasar akademik berupa kemampuan membaca, menulis, dan berhitung melainkan juga berfungsi menyiapkan lulusannya untuk melanjutkan pendidikan ke Sekolah Menengah Pertama. oleh sebab itu proses pendidikan di Sekolah Dasar mengimplikasikan perlunya perubahan orientasi dalam beberapa aspek sistematiknya terutama berkenaan dengan substansi kemampuan yang harus dikembangkan.

Agar memiliki kesiapan yang baik untuk dapat melanjutkan ke sekolah lanjutan tingkat pertama maka anak Sekolah Dasar tidak hanya dibekali 
kemampuan membaca menulis dan berhitung melainkan juga harus disiapkan untuk memiliki kemampuan intelektual kemampuan pribadi serta kemampuan sosial yang baik sesuai dengan tingkat perkembangannya.

Pengembangan kemampuan intelektual siswa Sekolah Dasar diperlukan karena tuntutan belajar di sekolah menengah pertama tidak hanya berkenaan dengan hafalan sejumlah pengetahuan dasar umum melainkan kemampuan pemahaman prinsip-prinsip ilmiah serta kemampuan memecahkan masalah yang efektif dengan menggunakan prinsip-prinsip ilmiah tersebut. Pengembangan kemampuan pribadi bagi siswa Sekolah dasar diperlukan agar dia memiliki ketahanan pribadi dan kemampuan penyesuaian yang tepat dalam menghadapi tuntutan dan lingkungan belajar di Sekolah Menengah Pertama.

Rendahnya kemampuan siswa Sekolah Dasar menjadi salah satu menyebab rendahnya mutu pendidikan kita. Sehingga pendidikan Sekolah Dasar menjadi acuan pertama keberhasilan pendidikan. Keberhasilan siswa di jenjang pendidikan Sekolah Dasar tidak lepas dari keberhasilan guru dalam melakukan fungsinya. Guru yang berhasil tentu adalah guru yang profesional di bidangnya.

Peraturan Menteri Pendidikan Nasonal Nomor 16 Tahun 2007 Pasal 1 ayat (1) "Setiap guru wajib memenuhi standar kualifikasi akademik dan kompetensi guru yang berlaku secara nasional.” Ada dua kualifikasi akademik guru yaitu kualifikasi guru melalui pendidikan formal dan kualifikasi guru melalui uji kelayakan dan kesetaraan. kualifikasi akademik merupakan jenjang akademik yang dipersyaratkan untuk dapat diangkat sebagai guru dalam bidang-bidang khusus yang sangat diperlukan tetapi belum dapat dikembangkan di perguruan tinggi dapat diperoleh melalui uji kelayakan dan kesetaraan. Uji kelayakan dan kesetaraan bagi seseorang yang memiliki keahlian tanpa ijazah dilakukan oleh perguruan tinggi yang diberi wewenang untuk melaksanakannya. 
Kualifikasi akademik guru pada satuan pendidikan jalur formal mencakup kualifikasi akademik guru pendidikan Anak Usia Dini/ Taman Kanak-kanak/Raudatul Atfal (PAUD/TK/RA), guru Sekolah Dasar/Madrasah Ibtidaiyah (SD/MI), guru Sekolah Menengah Pertama/Madrasah Tsanawiyah (SMP/MTs), guru Sekolah Menengah Atas/Madrasah Aliyah (SMA/MA), guru Sekolah Dasar Luar Biasa/Sekolah Menengah Luar Biasa/Sekolah Menengah Atas Luar Biasa (SDLB/SMPLB/SMALB), dan guru Sekolah Menengah Kejuruan/Madrasah Aliyah Kejuruan (SMK/MAK). Guru pada PAUD/TK/RA harus memiliki kualifikasi akademik pendidikan minimum diploma empat (D-IV) atau sarjana (S1) dalam bidang pendidikan anak usia dini atau psikologi yang diperoleh dari program studi yang terakreditasi. Guru pada $\mathrm{SD} / \mathrm{MI}$, atau bentuk lain yang sederajat, harus memiliki kualifikasi akademik pendidikan minimum diploma empat (D-IV) atau sarjana (S1) dalam bidang pendidikan SD/MI (D-IV/S1 PGSD/PGMI) atau psikologi yang diperoleh dari program studi yang terakreditasi.

Pentingnya peningkatan kemampuan professional guru Sekolah Dasar dapat di tinjau dari beberapa sudut pandang. Pertama, di tinjau dari perkembangan ilmu pengetahuan dan teknologi pendidikan. Seiring dengan perkembangan ilmu pengetahuan dan teknologi yang pesat, telah berhasil dikembangkan berbagai metode dan media baru dalam pembelajaran. Begitu juga dengan pengembangan materi dalam rangka pencapaian target kurikulum. Semuanya harus di kuasai oleh guru dan kepala Sekolah Dasar. Sehingga mampu mengembangkan pembelajaran yang dapat membawa anak didik menjadi lulusan yang berkualitas tinggi. Oleh sebab itu peningkatan kemampuan professional guru Sekolah Dasar perlu dilakukan secara kontinu. Seiring dengan perkembangan ilmu pengetahuan dan teknologi. Kedua, di tinjau dari kepuasan dan moral kerja. 
Peningkatan professional guru di Sekolah Dasar dapat dikelompokkan menjadi dua macam pembinaan. Pertama, pembinaan kemampuan pegawai Sekolah Dasar melalui supervisi pendidikan, program sertifikasi, dan tugas belajar. Kedua, pembinaan komitmen pegawai Sekolah Dasar melalui pembinaan kesejahteraannya.

Peningkatan kemampuan profesional guru Sekolah Dasar dapat dilakukan melalui supervisi pendidikan. Supervisi pendidikan merupakan proses pemberian layanan bantuan professional kepada guru untuk meningkatkan kemampuannya dalam melaksanakan tugas-tugas pengelolaan proses pembelajaran secara efektif dan efisien. Ada tiga ciri supervisi pendidikan. Pertama, supervisi pendidikan merupakan sebuah proses. Kedua, supervisi merupakan aktivitas membantu guru meningkatkan kemampuan dalam melaksanakan tugas-tugasnya, khususnya dalam mengelola proses belajar mengajar. Ketiga tujuan akhir pendidikan adalah guru semakin mampu mengelola proses pembelajaran secara efektif dan efisien.

Program sertifikasi merupakan salah satu bentuk pembinaan profesionalisme guru yang melibatkan banyak pihak, seperti sekolah, guru, Kepala Kantor Dinas Pendidikan Nasional Kabupaten/Kota, dan LPTK (Lembaga Pendidikan Tenaga Kependidikan). Program sertifikasi bertujuan untuk menyiapkan tenaga guru Sekolah Dasar dan madrasah ibtidaiyah yang berkualitas. Hasil yang diharapkan melalui program sertifikasi adalah sebagai berikut.

Pada masa sekarang ini sedang gencar-gencarnya pembinaan agar guru menjadi tenaga yang professional, pemerintah melalui undang- undangnya menetapkan undang-undang guru dan dosen dimana para pendidik disyaratkan telah lulus SI untuk TK/RA, SD/MI, SMP/MTs, SMA/MA/SMK dan disyaratkan lulus S2 untuk tenaga pengajar di Universitas (UU No. 14 Tahun 
2005 tentang undang-undang guru dan dosen). Implikasi dari keputusan tersebut maka guru Sekolah Dasar lulusan SPG atau PGA, dan Diploma II PGSD perlu ditugas belajarkan dalam bentuk program penyetaraan Strata 1 PGSD.

Semua yang dilakukannya untuk menyekolahkan guru Sekolah Dasar di atas, baik dalam bentuk program penyetaraan Strata 1 PGSD maupun menyekolahkannya ke LPTK dimaksudkan untuk meningkatkan profesionalisme guru. Oleh karena itu, tugas belajar dapat ditempuh dalam rangka pembinaan profesionalisme pegawai di Sekolah Dasar. Ada tiga tujuan yang dapat dicapai dengan pemberian tugas belajar kepada guru di Sekolah Dasar.

1) Meningkatkan kualifikasi formal guru sehingga sesuai dengan peraturan kepegawaian yang diberlakukan secara nasional maupun yayasan yang menaunginya.

2) Meningkatkan kemampuan profesional para guru Sekolah Dasar dalam rangka meningkatkan kualitas penyelenggaraan pendidikan di Sekolah Dasar.

3) Menumbuhkembangkan motivasi para pegawai Sekolah Dasar dalam rangka meningkaitkan kinerjanya.

Pembinaan profesionalisme guru Sekolah Dasar dapat juga diupayakan melalui sistem yang disebut dengan sistem pembinaan profesional guru (SPPGuru). Sistem pembinaan profesional (SPP) adalah suatu sistem pembinaan yang diberikan kepada guru dengan menekankan bantuan pelayanan profesi berdasarkan kebutuhan guru di lapangan melalui berbagai wadah profesional dalam rangka peningkatan mutu pendidikan. Sistem pembinaan profesional, pada dasarnya, menerapkan prinsip pembinaan antara teman sejawat dalam peningkatan kemampuan profesional guru yang dilakukan secara terus-menerus yang dilandasi oleh tujuan dan semangat untuk maju bersama. Sistem pembinaan profesional di Sekolah Dasar bertujuan untuk meningkatkan kemampuan profesional para guru Sekolah Dasar dalam rangka meningkatkan mutu proses 
dan hasil belajar siswa dengan mendayagunakan segala sumber daya dan potensi yang dimiliki sekolah, tenaga kependidikan, dan masyarakat sekitarnya. ${ }^{16}$

\section{SIMPULAN}

Memasuki era globalisasi yang ditandai dengan terjadinya perubahanperubahan yang bersifat global di berbagai bidang kehidupan, seperti perkebangan teknologi yang melahirkan berbagai produk teknologi komunikasi, robot dan laser. Kemajuan teknologi tersebut di satu sisi memberikan berbagai kemudahan bagi manusia, di sisi lain dapat menimbulkan dampak buruk baik jangka pendek maupun jangka panjang. Masyarakat dituntut untuk mampu melakukan pilihan yang tepat dalam menggunakan pilihan tersebut.

Guru memegang peran utama dalam keberhasilan pendidikan harus memiliki profesionalisme dalam menjalankan tugasnya. Terutama guru yang mendidik di pendidikan Sekolah Dasar. Selain itu guru juga seharusnya memahami konsep keislaman dalam menjalankan perannya.

Pembinaan profesionalisme guru Sekolah Dasar dapat juga diupayakan melalui sistem yang disebut supervisi pendidikan, sertifikasi, dengan sistem pembinaan profesional guru (SPP-Guru) dan tugas belajar. Program pembinaan tersebut berguna untuk meningkatkan kualitas guru sehingga berdampak positif terhadap keberhasilan pendidikan.

\section{DAFTAR PUSTAKA}

Hamzah B. Uno, Profesi Kependidikan.Jakarta: Sinar Grafika Offset.2008

Ibrahim Bafadal, Peningkatan Profesional Guru Sekolah Dasar, Jakarta: Bumi Aksara.2003

${ }^{16}$ https://oktaseiji.wordpress.com 
Kunandar. Guru Profesional Implemantasi Kurikulkum Tingkat satuan Pendidikan (KTSP) dan Sukses dalam Sertifikasi Guru.Jakarta:PT RajaGrafindo Persada, 2007

Muhammad Ismail Yusanto, dkk, Menggagas Pendidikan Islami, cet. I, Bogor: AlAzhar, 2004.

Nana Sudjana, Dasar-Dasar Proses Belajar Mengajar, Bandung: Sinar Baru, 1989

Oemar Hamalik, Pendidikan Guru Berdasarkan Pendekatan Kompetensi, Cet Ke-4, Jakarta: Bumi Aksara, 2006

Soetjipto. Profesi Keguruan. Jakarta : Rineka Cipta, 2004.

Tilaar.Manajemen Pendidikan Nasional. Bandung : PT. Remaja Rosdakarya.1999.

Tim Broad-Based Education. Konsep Pendidikan Berorientasi Kecakapan Hidup (life Skill) Melalui Pendekatan Pendidikan Berbasis Luas (Broad-Based EducationBBE). Jakarta : Depdiknas. 2002

http://staffnew.uny.ac.id https://oktaseiji.wordpress.com www.kompasiana.com 